(Received June 24, 1982)

\title{
ADDITION REACTION OF MULTIFUNCTIONAL EPOXIDES WITH WOOL KERATIN
}

\author{
By Yoshio Tanaka*1 and Hideki Shiozaki*2 \\ "I (Research Institute for Polymers \& Textiles, 1-1-4 Yatabe- \\ Higashi, Tsukuba, Ibaraki 305) \\ *2 (Industrial Research Institute of Kanagawa, 3173 Kanazawa- \\ Tomioka, Yokohama, Kanagawa 236, Japan)
}

\begin{abstract}
The heterogeneous addition reaction of $\mathrm{di}$ - and trifunctional epoxides with wool keratin was investigated in carbon tetrachloride and toluene at $50-75^{\circ} \mathrm{C}$, by using an aqueous solution of various salts as padding catalysts. The reaction rates depended on the nature of the salt, the epoxide and the solvent, and on the temperature. The rate increased with the salt concentration and reached a maximum value at a certain concentration of the salt. The effect of salt was attributed to the basicity or the nucleophilicity of the anions. The weight gains were described mainly by the reaction of the epoxide with the hydroxyl groups of the tyrosine and serine residues, although lysine, histidine, arginine and cystine residues were found to react. The wool fabrics treated with the epoxides were imparted with lower solubility in $\mathrm{HCOOH} / \mathrm{H}_{2} \mathrm{O}_{2}$ and $\mathrm{NH}_{4} \mathrm{OH}$ solutions, and with poorer resistance to aqueous $\mathrm{NaOH}$ solutions.
\end{abstract}

\section{Introduction}

The salt-catalyzed addition reaction of epoxides with protein fibers has been under investigation in our laboratories for these years. The addition of 2,3-є poxy-1-propyl phenyl ether ${ }^{1}$, and a number of other epoxides ${ }^{2,3}$. such as 1,2-epoxypropane, 1-chloro-2,3-epoxypropane, and phenyloxirane, with wool fabric has been subjects of our previous reports: Histidine, lysine, arginine, serine, tyrosine, cystine, and asparatic and glutamic acids have been found to react with the epoxides. The effects of salts as catalysts, solvents and the substituents of the epoxides have been also discussed ${ }^{2,3)}$.

If the reactive side groups on the polypeptide chains of the keratin are covalently bridged with multifunctional epoxides in the presence of a salt, then the improved properties imparted to the wool fiber are more than those attained by the reaction with monoepoxides. The literature contains some references to the treatments of wool fibers with diepoxides, such as 3,4-isopropylidene-1,2,5,6dianhydromannitol ${ }^{4}$, 1,2,3,4-diepoxybutane and 1,2,5,6-diepoxyhexane ${ }^{5)}$ in aqueous buffered solutions, and suggests that the epoxides react with the acidic and basic amino acid residues of the keratin, but so far the investigations are still of qualitative nature. Consequently, this paper deals with the salt-cacalyzed addition reaction of di- and trifunctional epoxides with wool keratin, and discusses some feature of the reactions and the effect of modification of the wool fabric compared with the reaction of monoepoxides reported previously ${ }^{1-3)}$. A preliminary part of the reaction has already been communicated ${ }^{6)}$ and the present paper gives details of the reaction.

\section{Experimental}

\section{Materials}

A plain weave fabric (wool muslin, a Merino top, 67 's quality) was treated with a $0.3 \%$ aqueous solution of Marseilles soap and with water at $70^{\circ} \mathrm{C}$. The wool swatch was extracted with benzene and ethanol in a Soxhlet apparatus for $9 \mathrm{hr}$ and rinsed with ethanol and distilled water. All epoxides used were commercial products (See Table 1). All of salt catalysts and organic solvents were of reagent grade and were used without further purification.

\section{Reaction Procedure}

A $0.4 \mathrm{~g}$ swatch dried in a forced draft oven at $105^{\circ} \mathrm{C}$ for $45 \mathrm{~min}$ was impregnated with the desired aqueous salt solution to an approximate $95 \%$ wet pickup. The loosely rolled swatch was 
Table 1. Multifunctional Epoxides.

\begin{tabular}{|c|c|c|c|}
\hline Main Composition & Commercial Name & Epoxy Equivalent & Symbol \\
\hline Glycerol triglycidyl ether ${ }^{\text {a }}$ & Epikote 812 (Shell) & $140-160$ & TEG \\
\hline Ethylene glycol diglycidyl ether ${ }^{b}$ & Epikote 562 (Shell) & 101 & DEE \\
\hline Resorcinol diglycidyl ether ${ }^{e}$ & Araldite ERE1359 (Ciba) & 128 & DER \\
\hline 1,4-Butanediol diglycidyl ether ${ }^{\text {d }}$ & Araldite DY-022 (Ciba) & 136 & DEB \\
\hline 1,6-Hexanediol diglycidyl ether ${ }^{*}$ & Epolight 1600 (Kyoei) & $135-165$ & $\mathrm{DEH}$ \\
\hline Neopentyl glycol diglycidyl ether ${ }^{\mathrm{f}}$ & Denacol EX-211 (Nagase) & 140 & DEN \\
\hline Polyethylene glycol diglycidyl ether ${ }^{\mathrm{g}}$ & Epiol PE-06 (Nihon-oil) & 301 & DEP \\
\hline
\end{tabular}

a 1,2,3-Tris(2,3-epoxy-1-propoxy)propane

b 1,2-Bis(2,3-epoxy-1-propoxy)ethane

c 1,3-Bis(2,3-epoxy-1-propoxy)benzene

d 1,4-Bis(2,3-epoxy-1-propoxy)butane

e 1,6-Bis(2,3-epoxy-1-propoxy)hexane

f 2,2-Dimethyl-1,3-bis(2,3-epoxy-1-propoxy)propane

g $\mathrm{OCH}_{2} \mathrm{CHCH}_{2} \mathrm{O}\left(\mathrm{CH}_{2} \mathrm{CH}_{2} \mathrm{O}\right)_{n} \mathrm{CH}_{2} \mathrm{CHCH}_{2} \mathrm{O}, n=10$

then dropped into a graduated cylindrical flask containing $15 \mathrm{ml}$ of a $5.0-10.0 \%$ epoxide solution in carbon tetrachloride or ethyl acetate; the flask was joined with a reflux condensor, held in a thermostatically controlled bath at the desired temperature, and occasionally shaken during the reaction time. At the end of the reaction, the sample was washed with the solvent used and acetone, extracted with boiling mixture $(2 / 1, v / v)$ of acetone and chlorobenzene for $30 \mathrm{~min}$, and rinsed with methanol and finally with distilled water. The washed and air-dried fibers were dried in an oven at $105^{\circ} \mathrm{C}$, placed in a desiccator over the silica gel for $30 \mathrm{~min}$, and weighed. The add-ons or weight gains were determined from the weight increase of the fiber, a correction being made for the weight loss on treatment with the salt alone.

\section{Amino Acid Analysis}

Dried wool fiber weighing about $200 \mathrm{mg}$, untreated or treated with epoxides, was hydrolyzed by heating for $8 \mathrm{hr}$ at $1.05-108^{\circ} \mathrm{C}$ in $20 \mathrm{ml}$ of aqueous $6 \mathrm{~N} \mathrm{HCl}$. The amino acid contents were determined on a buffered solution $(\mathrm{pH} \mathrm{2.2)}$ of the hydrolyzate $(0.2 \mathrm{mg} / 0.1 \mathrm{ml})$ by using d JLC- $5 \mathrm{AH}$ amino acid analyzer (JEOL Ltd.).

\section{Test Methods}

The solubility test in an aqueous solution of $\mathrm{NaOH}$ was performed as suggested by Zahn and Willhelm ${ }^{7}$, by treating a sample of about $0.4 \mathrm{~g}$ with $40 \mathrm{ml}$ of 0.1 or $0.25 \mathrm{~N} \mathrm{NaOH}$ solution at $65^{\circ} \mathrm{C}$ for $1 \mathrm{hr}$. The solubility test in aqueous solutions of $\mathrm{HCOOH} / \mathrm{H}_{2} \mathrm{O}_{2}$ and of $0.3 \mathrm{~N} \mathrm{NH}_{4} \mathrm{OH}$ was made at $0^{\circ} \mathrm{C}$ for $20 \mathrm{hr}$, and at $20^{\circ} \mathrm{C}$ for $20 \mathrm{hr}$, respectively, as suggested by $\mathrm{Griffith}^{8)}$.

\section{Results and Discussion}

The diglycidyl ether of ethylene glycol or 1,2bis(2,3-epoxy-1-propoxy) ether (DEE) was used for study on the effect of reaction conditions such as time, temperature, salt concentration, nature of salts and solvents. The fabrics padded with various concentrations of $\mathrm{KSCN}$ in aqueous solutions were treated with a $5 \mathrm{wt}$ \% solution of DEE and the diglycidyl ether of resorcinol, i.e., 1,3-bis(2,3epoxy-1-propoxy)benzene (DER), in carbon tetrachloride at $68^{\circ} \mathrm{C}$ for $3 \mathrm{hr}$. The weight gains are found to vary with the concentration of the salt in the padding solution as shown in Figure 1. The addition of multifunctional epoxides to wool resulted in an appreciable increase of the race with increasing a salt concentration, in contrast to the reaction with monoepoxides, in which the catalytic efficiency of the salt was not so much ${ }^{2)}$. Figure 1 shows, moreover, the heterogeneous reaction proceeded successfully in this solution without the catalyst as well as that with monoepoxides ${ }^{1-3)}$. This can be attributed partly to the participation of amino and carboxylic groups, particularly histidine, lysine, and aspartic and glutamic acids in the uncatalyzed reaction. 


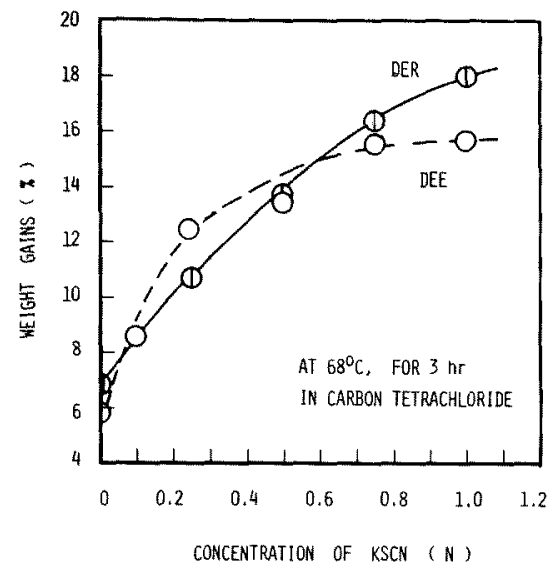

Fig. 1. Concentration effect of aqueous $\mathrm{KSCN}$ padding solution on the weight gains of wool keratin in the reaction of DEE and DER at $68^{\circ} \mathrm{C}$ for $3 \mathrm{hr}$ in carbon tetrachloride.

In succeeding experiments the time dependence of the reaction was investigated, and the results are shown in Figure 2, in which the effect of temperature can be also observed. The reaction of DEE was carried out with use of $0.25 \mathrm{~N}$ aqueous KSCN solution as a padding catalyst, and with carbon tetrachloride as a solvent at $53-68^{\circ} \mathrm{C}$. The add-ons increased monotonously with time and were depended on the temperature. These variations of the weight gains with time are similar to those in the reaction of silk fibroin with an epoxide ${ }^{9)}$, while for the hydroxy ion-catalyzed reaction of cellulose with an epoxide the weight gains on cellulose have been found to vary linearly with time of reaction ${ }^{10}$.

The wool fabric was padded with $0.25 \mathrm{~N}$ aqueous KSCN solution to $95 \%$ wet pickup and then treated with various multifunctional epoxides in carbon tetrachloride at $68^{\circ} \mathrm{C}$. Variations of weight gains of the fabrics are shown at various times in Figure 3. The reaction with the triglycidyl ether, 1,2,3-tris (2,3-epoxy-1-propoxy) propane (TEG), resulted in the greatest weight gains, while moderate weight gains $(16-18 \%)$ were obtained with DEE and DER. The other diglycidyl ethers, such as diglycidyl ether of polyethylene glycol (DEP), 1,4-bis(2,3-epoxy-1-propoxy)butane (DEB), 2,2dimethyl-1,3-bis (2,3-epoxy -1 - propoxy) propane (DEN), and 1,6-bis (2,3-epoxy-1-propoxy)hexane

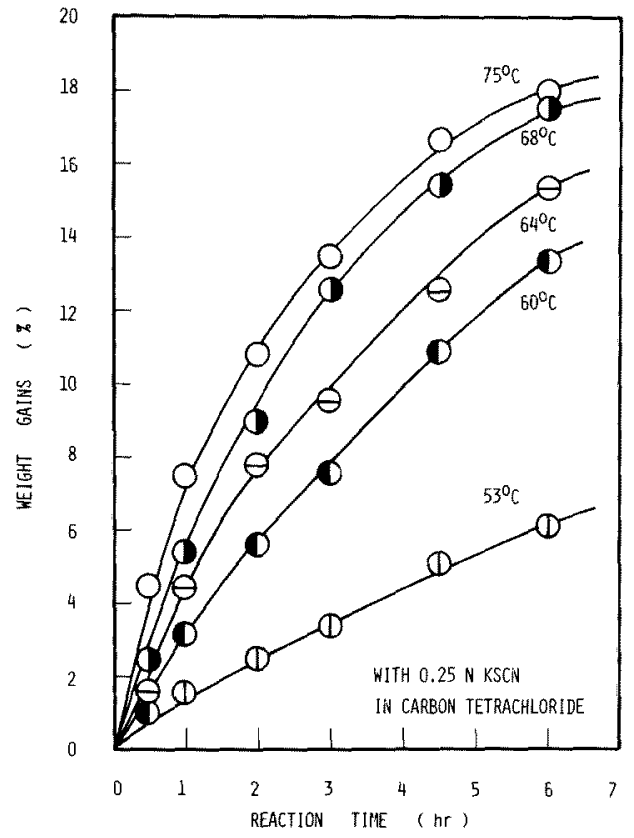

Fig. 2. Time-conversion curves for the wool keratin reaction with DEE in carbon tetrachloride at various temperatures, using $0.25 \mathrm{~N}$ aqueous $\mathrm{KSCN}$ solution as padding catalyst.

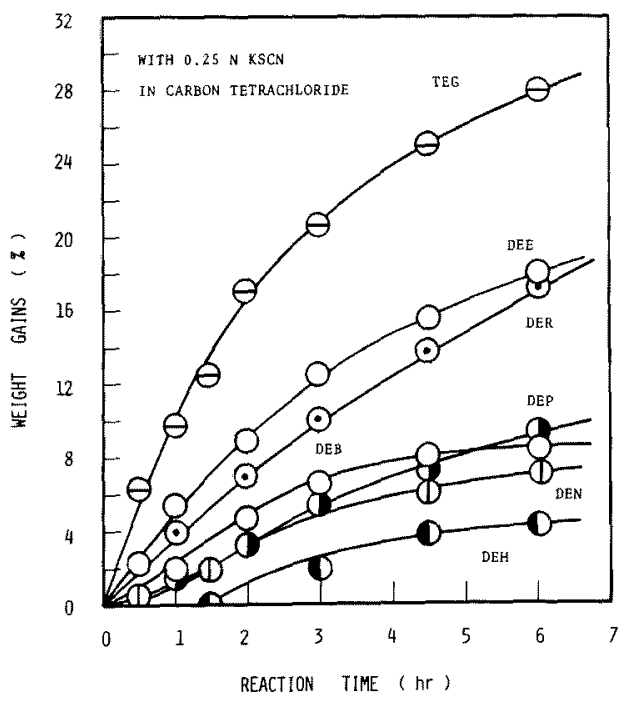

Fig. 3. Time-conversion curves for the wool keratin reaction with various epoxides at $68^{\circ} \mathrm{C}$ in carbon tetrachloride, using $0.25 \mathrm{~N}$ aqueous $\mathrm{KSCN}$ solution as padding catalyst. 
(DEH), gave smaller add-ons up to $9 \%$. The reactivity of DEB toward wool keratin was found to be lower than that toward silk fibroin 9 ). and the similar reactivity difference between TEG and $\mathrm{DEE}$ in these wool reaction was also observed in the silk reaction ${ }^{9}$ ).

The ring-opening reaction of the epoxide can be generally explained by the modified $T a f t$ equation ${ }^{11)}$, and the steric substituent factor of the epoxide was found to play a more important role than the polar factor in the salt-catalyzed reaction of the silk fibroin") and with wool keratin ${ }^{2)}$ under these heterogeneous conditions, compared to other epoxide reactions in solutions. Thus the reactivity difference in these multifunctional epoxides toward wool keratin may be described partly by the steric factor such as the molecular size (measured as molecular volume) and shape (estimated form viscosity) in addition to the polar substituent factor.

Figure 4 shows the time-dependence of conversion of tyrosine, histidine, lysine, and cystine in the wool fabric, which was padded with $0.25 \mathrm{~N}$ aqueous $\mathrm{KSCN}$ solution and treated with DEE solution in carbon tetrachloride at $68^{\circ} \mathrm{C}$, and whose weight gains are shown in Figure 3. The reaction occurred very rapidly on lysine and histidine residues. The reaction on tyrosine residues was also rapid, while on arginine residues little occurred, $10 \%$ of its content having decreased by the reaction in this case. Although the

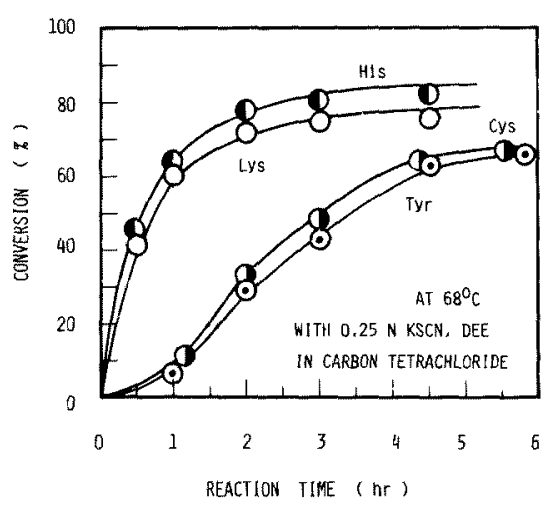

Fig. 4. Time-conversion curves of amino acid residues in wool keratin for the epoxide reaction at $68^{\circ}$ in carbon tetrachloride, using DEE and $0.25 \mathrm{~N}$ aqueous KSCN padding solution. content of arginine in silk fibroin is $10 \%$ or less of that in wool keratin, a half or more amount of arginine residues in the fibroin had reacted under the similar conditions ${ }^{9)}$. The cystine residues decreased with add-ons or with the reaction time. The reactivity differences among these active amino acid residues can be described partly by their dissociation constants. From this reactivity view point, the acidic groups from aspartic and glutamic acid residues should also react considerably with an epoxide to produce esters. The reaction with these carboxylic groups, however, cannot be estimated because the ester could be hydrolyzed easily under the analytical conditions to give the original carboxylic groups. The gasliquid chromatography of the hydrolyzate indicated $^{12)}$ that an epoxide reacted with these acidic residues.

A remarkable effect of salt or solvent was observed on this reaction as shown in Table 2 . Some sodium salts in aqueous solutions at the constant concentration of $1 \mathrm{~N}$ were used as pretreatments to catalyze the reaction of wool keratin with DEE in carbon tetrachloride at $75^{\circ} \mathrm{C}$ for $3 \mathrm{hr}$. Salts of the anions with higher nucleophilic reactivities such as $\mathrm{S}_{2} \mathrm{O}_{3}^{--}, \mathrm{SCN}^{-}$, and $\mathrm{CN}^{-}$caused higher add-ons, although the fabric was damaged by the salt of $\mathrm{CN}^{-}$which has the highest basicity of all anions studied and is found ${ }^{12)}$ to convert intermolecular cystine bridges in wool into intramolecular lanthionine crosslinks. Salts of $\mathrm{CH}_{3} \mathrm{CO}_{2}^{-}$, $\mathrm{I}^{-}, \mathrm{Cl}^{-}$, and $\mathrm{NO}_{3}^{-}$also could be classed as good catalysts. The effect of anions on this reaction could be described party by the reactivity of these anions in nucleophilic substitution reactions such as the Edwards' parameter $E_{n}{ }^{13)} ; E_{n}$-values of $\mathrm{S}_{2} \mathrm{O}_{3}^{--}, \mathrm{SCN}^{-}, \mathrm{CN}^{-}, \mathrm{CH}_{3} \mathrm{CO}_{2}^{-}, \mathrm{I}^{-}, \mathrm{Cl}^{-}$, $\mathrm{NO}_{3}^{-}, \mathrm{Br}^{-}$, and $\mathrm{SO}_{4}^{--}$are $2.52,1.83,2.79,0.95$, $2.06,1.24,0.29,1.51$, and 0.59 , respectively. Figure 5 shows a typical relationship between the weight gains or active amino acid contents and Edwards' $E_{n}$-value. The dispersion in this relationship suggests that a higher order interaction term of the bydration ability, the nucleophilicity, and the basicity of anions, or yet another factor plays a part in the wool-epoxide reaction catalyzed by the anions.

Table 2 also shows the effect of solvents. The solvent effect in the wool reaction with mono- 
Table 2. Remaining Amino Acid Contents of Wool Fabrics Reacted with DEE ${ }^{\mathrm{a}}$.

\begin{tabular}{|c|c|c|c|c|c|c|c|c|c|c|}
\hline \multicolumn{4}{|c|}{ Reaction Condition } & \multirow{2}{*}{$\begin{array}{c}\text { Add-ons } \\
\left.\text { (mole } / 10^{5} \mathrm{~g}\right)\end{array}$} & \multicolumn{6}{|c|}{ Reactive Amino Acid Contents (mole $/ 10^{5} \mathrm{~g}$ ) } \\
\hline Salt & Solvent & Temp. & Time & & Tyr & Ser & $\operatorname{Arg}$ & Lys & His & Cys \\
\hline $\mathrm{NaSCN}$ & $\mathrm{CCl}_{4}$ & $75^{\circ} \mathrm{C}$ & $3 \mathrm{hr}$ & 141.5 & 2.57 & 72.4 & 38.8 & 1.23 & 0.18 & 34.4 \\
\hline $\mathrm{NaBr}$ & $"$ & ' & " & 109 & 6.62 & 78.3 & 46.9 & 1.50 & 0.30 & 36.9 \\
\hline $\mathrm{Na}_{2} \mathrm{SO}_{4}$ & ' & ". & " & 86.2 & 24.1 & 76.1 & 47.8 & trace & 0.06 & 37.6 \\
\hline $\mathrm{NaNO}_{3}$ & “. & $"$ & $"$ & 89.2 & 23.1 & 83.0 & 51.5 & trace & 0.45 & 39.3 \\
\hline $\mathrm{NaCl}$ & " & ". & " & 94.1 & 6.53 & 80.0 & 51.0 & 0.49 & 0.41 & 39.2 \\
\hline $\mathrm{NaI}$ & $"$ & " & " & 98.5 & 4.76 & 86.4 & 49.3 & 0.08 & 0.31 & 40.8 \\
\hline $\mathrm{NaOCOCH}_{3}$ & " & " & ". & 107.4 & 4.63 & 86.3 & 43.4 & 0.37 & 0.27 & 36.2 \\
\hline $\mathrm{NaCN}$ & " & ' & " & 172 & 0.00 & 61.8 & 20.0 & 0.26 & 0.00 & 37.5 \\
\hline $\mathrm{Na}_{2} \mathrm{~S}_{2} \mathrm{O}_{3}$ & ' & 60 & 6 & 139.5 & 4.73 & 81.7 & 43.7 & 3.06 & 0.46 & 35.8 \\
\hline$"$ & $\mathrm{CH}_{3} \mathrm{CO}_{2} \mathrm{C}_{2} \mathrm{H}_{5}$ & " & " & 69.8 & 23.7 & 99.6 & 55.0 & 6.19 & 1.17 & 36.6 \\
\hline " & $\mathrm{C}_{6} \mathrm{H}_{5} \mathrm{CH}_{3}$ & ". & $"$ & 72.3 & 16.6 & 95.4 & 49.6 & 4.03 & 0.70 & 37.4 \\
\hline$"$ & $\mathrm{CH}_{3} \mathrm{COC}_{2} \mathrm{H}_{5}$ & & $"$ & 32.7 & 29.9 & 92.5 & 49.6 & 10.7 & 1.44 & 39.4 \\
\hline \multicolumn{2}{|c|}{ Untreated Wool } & - & - & 0.0 & 30.5 & 97.1 & 53.1 & 22.2 & 5.90 & 41.2 \\
\hline
\end{tabular}

${ }^{3}$ Fabric padded with a $1 \mathrm{~N}$ aqueous solution of the indicated salt was treated with DEE solution in the indicated solvent for the mentioned time. The contents of other amino acid residues did not change under the conditions.

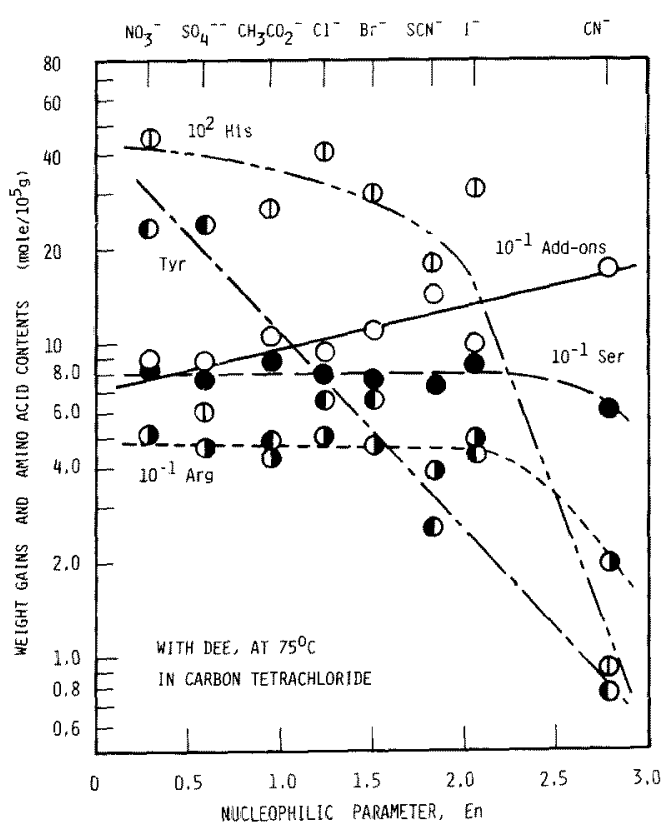

Fig. 5. Effect of nucleophilic parameter, $E_{n}$, of the anion in the padding solution on the weight gains and reactive amino acid contents of wool fabric. See also Table 2 .

$10^{-1}$ Add-ons; $10^{-1}$ Ser; $10^{-1}$ Arg;
$10^{-2}$ His; $\mathrm{Tyr}$. epoxides could be explained ${ }^{2,3)}$ in terms of the solubility parameter, not by the dielectric constant of the solvent used. This solvent effect can be also explained. Since the reaction may proceed in an aqueous phase containing salt and epoxide which enters from an organic phase, as discussed previously ${ }^{2,3)}$. the reaction rate should depend on the distribution of the epoxide in both phases and have a smaller value in a solvent whose solubility parameter is similar to that of the epoxide (ca. 9-10). Previous work ${ }^{1-3)}$ has shown the importance of the water and the salt contents of the fabric at the time of the wool-epoxide reaction. When water was extracted from the system, the rate decreased, and increased in the presence of a salt as shown in Figure 1. Hence, the reaction under consideration should be ionic and catalytic.

In the process of absorbing counterions, the ionized groups of the protein become neutralized $^{14)}$, as shown by Equations (1)-(3):

$$
\begin{aligned}
& \mathrm{RH}+\mathrm{MX}=\mathrm{RH} \ldots \mathrm{M}^{+} \text {or } \mathrm{RH} \ldots \mathrm{X}^{-} \\
& \mathrm{Ia} \\
& \mathrm{RH}+\mathrm{MX} \rightleftharpoons \mathrm{R}^{--} \mathrm{M}^{+} \text {or } \mathrm{RH}_{2}^{+} \mathrm{X}^{-} \\
& \mathrm{Ila} \\
& \mathrm{RH}+\mathrm{RH} \rightleftharpoons \mathrm{R}^{-}+\mathrm{RH}_{2}^{+} \\
& \mathrm{I} \text { or } \mathrm{II} \rightleftharpoons \mathrm{R}^{-} \text {or } \mathrm{RH}_{2}^{+}+\mathrm{M}^{+}+\mathrm{X}^{-}
\end{aligned}
$$


where $\mathrm{MX}$ is a salt, and $\mathrm{RH}$ is a proton-donating group, such as $\mathrm{NH}, \mathrm{NH}_{2}, \mathrm{OH}$, or $\mathrm{COOH}$ of histidine, lysine, arginine, tyrosine, serine, threonine, aspartic and glutamic acids of the protein. The electrochemical proterties of the protein have been found to depend on the kind and concentration of various salts present ${ }^{15,16)}$ and partly due to the secondary effect of the salt by the ionic strength of the solution ${ }^{17)}$. This secondary salt effect can explain one of the concentration effects of the salt, shown in Figure 1, because the concentration of active species such as $\mathrm{R} \overparen{\mathrm{CHCH}_{2} \mathrm{O}}$ $\ldots \mathrm{H}^{+}$has been found to depend on the concentration of the proton ${ }^{18)}$.

The ionization of acid groups of aspartic and glutamic acids corresponds to $\mathrm{pK} 3.65$ and 4.254.32 , and that of basic groups of histidine, lysine, and arginine agrees to $\mathrm{pK} 6.00$ (imidazole), 10.53 ( $\varepsilon$-amino) and 12.48 (guanido) $^{19)}$. The $\mathrm{pK}$ value for the phenolic hydroxyl group of tyrosine is approximately 10.1. The ionic groups of proteins are essentially the same as those of the amino acids, but the $\mathrm{pK}_{1}$ values of the peptides are higher by $0.8 \mathrm{pH}$ unit, and the $\mathrm{pK}_{2}$ values lower by 1.4 to $1.7 \mathrm{pH}$ units than those of the corresponding amino $\mathrm{acid}^{20)}$. Furthermore, some solvents such as alcohol or acetone change the dissociation constants of the proton-supplying groups (higher for acidic and lower for basic groups), and shift the isoelectric point to lower or higher $\mathrm{pH}$ values ${ }^{19)}$. Thus, these acidic and basic groups of the wool keratin seem to be ionized in 99 to $100 \%$ under these conditions, while the alcoholic hydroxyl group of serine and threonine is a very weak acid and practically unchanged in neutral of weakly basic solutions. Hence, the active species in this reaction may be ion-pairs like IIa for the carboxylic group and IIb for the amino groups and complexes such as I for hydroxyl groups.

In order to explain the available data, the following reaction sequence, suggested by us in the silk reaction"), is proposed:

$$
\mathrm{R}^{-} \mathrm{M}^{+}+\mathrm{R}^{\prime} \stackrel{\mathrm{CHCH}_{2} \mathrm{O}}{\longrightarrow} \stackrel{\mathrm{H}^{+}}{\longrightarrow} \mathrm{RCH}_{2} \mathrm{CHR}^{\prime} \mathrm{OH} \ldots \mathrm{M}^{+}
$$

$$
\mathrm{RH}_{2}^{+} \mathrm{X}^{-}+\mathrm{R}^{\prime} \stackrel{\mathrm{CHCH}}{2} \mathrm{O} \rightarrow \mathrm{RCH}_{2} \mathrm{CHR} \cdot \mathrm{OH}\left(\mathrm{H}^{+}\right) \mathrm{X}^{-}
$$

$$
\mathrm{RH} . . . \mathrm{X}^{-}+\mathrm{R}^{\prime} \overparen{\mathrm{CHCH}} \mathrm{O}_{2} \rightarrow \mathrm{RCH}_{2} \mathrm{CHR}^{\prime} \mathrm{OH} . . . \mathrm{X}^{-}
$$

where, $\mathrm{R}$ is $\mathrm{R}^{\prime \prime} \mathrm{CO}_{2}$ in Equation (4), R"NH or $\mathrm{R}^{\prime \prime} \mathrm{N}$ in Equation (5), and $\mathrm{R}^{\prime \prime} \mathrm{O}$ in Equation (6), and $R^{\prime}$ and $R^{\prime \prime}$ are any of the possible organic moieties of the epoxide and the proteins, respectively. In the reaction shown by Equation (4), protons may be supplied from the complexes I or the ion-pairs IIb, and possibly also from the water. Besides the above main processes, the following sequence may occur in some degree too:

$$
\mathrm{RH} \ldots \mathrm{M}^{+}+\mathrm{R}^{\prime} \mathrm{CHC \textrm {H } _ { 2 } \mathrm { O }} \rightarrow \mathrm{RCH}_{2} \mathrm{CHR}^{\prime} \mathrm{OH} \ldots \mathrm{M}^{+}
$$

where $\mathrm{R}$ is $\mathrm{R}^{\prime \prime} \mathrm{NH}$ or $\mathrm{R}^{\prime \prime} \mathrm{N}$. In the reaction of Equation (6), RH is the phenolic hydroxyl group from tyrosine or the carboxyl group from aspartic and glutamic acids.

If the transition-state species or activated complex is of type IIIb or IIId, the catalytic efficiency of the anions can be elucidated by their basicity which is a measure of the nucleophilic reactivity towards protons, or by their nucleophilicity towards carbon atom. The basicity may play an important part for the transition-state species IIIb, while the nucleophilic reactivity towards carbon atom, such as the Swain-Scott parameter $n$ and the Edwards' parameter $E_{n}$ must play a part for an activated complex such as IIId ${ }^{21}$, because the steric constant in IIId should be greater than that in the corresponding ion-pairs of type lilb. In this wool-epoxide reaction, transition-state species of type IIIa, IIIb, and IIId may play a more important role than IIIc, because the weight gains depend on the conversion of dissociated carboxylic and amino groups and of undissociated phenolic hydroxyl group of tyrosine (See Table 2); therefore, the add-ons can be explained by the basicity and the nucleophilicity. The hydroxyl groups produced in
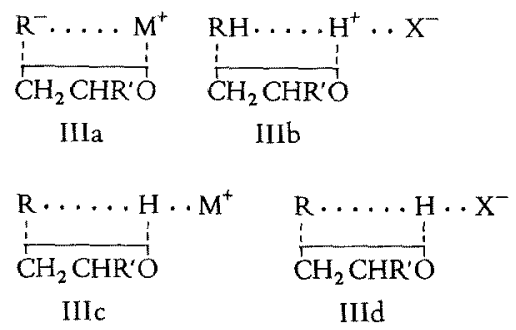
reactions (4)-(7) seem to be unreactive to epoxides or less reactive than those of serine under these conditions. The reactivity differences among the active amino acid residues of the wool may be explained by the reactivity of the corresponding transition-state species or activated complexes of III. As mentioned in Figure 4, the conversion of tyrosine and cystine follows a sigmoidal curve showing an induction period, which suggests the reaction of the transition-state species like IIIc and IIId is of autocatalytic nature, compared with that concerned with the activated complexes of type IIIa $\left(\mathrm{R}=\mathrm{R}^{\prime \prime} \mathrm{CO}_{2}\right)$ and IIIb ( $\mathrm{R}=\mathrm{R}^{\prime \prime} \mathrm{N}$ or $\left.\mathrm{R}^{\prime \prime} \mathrm{NH}\right)$.

The contents of reactive amino acid residues in untreated wool fabric are found ${ }^{11}$ as: Tyr, 31 ; Ser, 99; Arg, 52; Lys, 21; His, 6; Cys, 40; Asp, 53; Glu, 94 mole $/ 10^{5} \mathrm{~g}$ (total, $396 \mathrm{~mole} / 10^{5} \mathrm{~g}$ ). If a $n$-functional epoxide reacts with $n(n=1,2,3, \ldots)$ reactive amino acid residues in peptide to form crosslinks, $396 / n$ mole $/ 10^{5} \mathrm{~g}$ of the epoxide would be needed for the complete reaction. Neither appreciable increase nor decrease in the weight and in the amino acid content of the wool fabric was observed in the present conditions after the wool padded with an aqueous salt solution was treated with the solvents used here, although the fabric was damaged by the salt of $\mathrm{CN}^{-}$which is found ${ }^{12}$ ) to convert intermolecular cystine bridges in wool into intramolecular lanthionine crosslinks. With a diepoxide like DEE, hence, only one-half a mole may be needed for crosslinking. Thus, if one molecule of the epoxide reacts with two reactive amino acid residues, the amount of reacted acidic groups from aspartic and glutamic acid residues can be calculated by Equation (8);

$$
\begin{aligned}
{[\text { Asp }]+[\text { Glu }]=} & 2[\mathrm{~W}-([\mathrm{Tyr}]+[\mathrm{Ser}]+[\text { Arg }] \\
& +[\text { Lys }]+[\text { His }]+[\text { Cys }]) / 2]
\end{aligned}
$$

where $[X]$ ( $X=$ Asp, Arg, Cys, Glu, His, Lys, Ser, and $T y r)$ is a reacted amount of reactive amino acid residue, $X$, and $W$ is a weight gains or add-ons, in mole $/ 10^{5} \mathrm{~g}$, respectively. Using the data in Table 2, total amount of reacted acidic groups from aspartic and glutamic acids in wool keratin could be estimated as (weight gains and reacted aspartic and glutamic acids are given in mole $/ 10^{5} \mathrm{~g}$ ): 33,$39 ; 70,107 ; 72,98 ; 86,108 ; 89,126 ; 94$, $116 ; 98,129 ; 107,136 ; 109,139 ; 140,198 ; 142$,
$183 ; 172,214$. Since total amount of these acidic groups is $147 \mathrm{~mole} / 10^{5} \mathrm{~g}$ (Asp, 53 and Glu, 94 mole $/ 10^{5} \mathrm{~g}$ ), the crosslinks of the fiber can be sufficiently expected to be formed by the reaction of the wool keratin with these diepoxides. Some estimated values of the reacted acidic groups (198, 183 and 214 mole $/ 10^{5} \mathrm{~g}$ ) are larger than the total amount of aspartic and glutamic acids residues, as mentioned above, and, thus, suggest that other reactions to form no crosslinks also take place in part.

Table 3 shows the typical results of the solubility test on wool fabrics treated with multifunctional epoxides in solution. The considerable decrease of the solubility was found in every case to the treatment in performic acid/ammonium hydroxide solution. The solubility in alkali shows an increase except with DER (17\% of add-ons). With 1-chloro-2,3-epoxypropane, a similar increase of solubility in aqueous $\mathrm{NaOH}$ solution was also found ${ }^{7)}$ to be a result of chemical modification. This is inconsistent with the result of the solubility test for the silk treated with multifunctional epoxides under similar conditions ${ }^{9}$.

The solubility test measures the ease with which wool is chemically attacked by a reagent. The acid or alkali solubility of a large number and variety of modified wools has been determined by Zahn and coworkers ${ }^{7}$, and by Koenig ${ }^{22}$. The over-all data indicate that the number of acidic and basic groups in the modified wool is a significant factor in its solubility. As mentioned by Equations (4) - (7), the modification with epoxides decreases the acidic groups such as carboxyl and phenol groups, and increases alcoholic hydroxyl groups which are of hydrophilic nature. The decrease of acidic groups which results from modification with epoxides would decrease the alkali solubility, if the acid-base character of the treated wool were the only influence on these solubilities. Treatments with the epoxide, in contrast, result in the higher alkali solubilities than that of unmodifjed wool.

Another factor influencing solubilities may be the polarity or hydrophilicity of the substituents. In particular, nonpolar or hydrophobic substituents such as long-chain hydrocarbon and phenyl groups like that of DER can provide a nonpolar or hydrophobic environment less favorable to acid and 
Table 3. Solubilities of Wool Fabrics in $\left(\mathrm{HCOOH} / \mathrm{H}_{2} \mathrm{O}_{2}\right) / \mathrm{NH}_{4} \mathrm{OH}$ and in $\mathrm{NaOH}$ Solutions ${ }^{\mathrm{a}}$.

\begin{tabular}{|c|c|c|c|c|}
\hline \multirow[t]{2}{*}{ Epoxide } & \multirow{2}{*}{$\begin{array}{c}\text { Add-ons } \\
(\%)\end{array}$} & \multirow{2}{*}{$\begin{array}{c}\left(\mathrm{HCOOH} / \mathrm{H}_{2} \mathrm{O}_{2}\right) / \mathrm{NH}_{4} \mathrm{OH}^{\mathrm{b}} \\
(\%)\end{array}$} & \multicolumn{2}{|c|}{$\mathrm{NaOH}^{\mathrm{c}}(\%)$} \\
\hline & & & $0.10 \mathrm{~N}$ & $0.25 \mathrm{~N}$ \\
\hline DEE & $4.3-4.5$ & 27.2 & 13.0 & 33.6 \\
\hline ". & $7.4-7.7$ & 24.0 & 11.3 & 30.0 \\
\hline ." & 9.6 & - & 12.9 & - \\
\hline " & $11.6-12.5$ & 26.3 & 13.8 & 31.5 \\
\hline ." & 17.9 & 29.8 & - & - \\
\hline DER & $3.6-3.9$ & 57.3 & 12.5 & 33.6 \\
\hline " & $6.7-7.0$ & 49.7 & 11.8 & 35.5 \\
\hline$"$ & 9.3 & 29.0 & - & - \\
\hline " & 13.7 & - & 10.0 & 30.9 \\
\hline . & $14.5-14.7$ & 48.3 & 9.2 & 23.5 \\
\hline ." & 17.2 & 31.3 & 9.3 & 19.0 \\
\hline TEG & $12.1-15.5$ & 24.5 & 12.4 & 36.2 \\
\hline DEP & 5.4 & 25.4 & 12.8 & 35.8 \\
\hline " & 9.4 & 26.1 & 18.9 & 37.5 \\
\hline DEB & 7.0 & 31,1 & - & - \\
\hline " & 10.4 & 26.1 & - & - \\
\hline DEN & 5.9 & 21.7 & - & - \\
\hline None & 0.0 & 80.9 & 11.9 & 26.0 \\
\hline
\end{tabular}

a Wool fabric padded with $0.25 \mathrm{~N}$ aqueous $\mathrm{KSCN}$ solution was treated with various epoxides in $\mathrm{CCl}_{4}$ at $68^{\circ} \mathrm{C}$ for various times.

b By the similar method of Griffith's ${ }^{8)}$.

c By the similar method of Zahn and Wilhelm?).

alkali attack. Steric effects of substituents in modification should also influence such chemical solubility, but no data in this experiment show a part of the factor; a properly located large substituent might shield vulnerable areas such as the disulfide bond region. Accordingly, the net effect of modification on alkali solubility reflects various substitution influences, including change of acidbase character, steric factors, and polarity or hydrophilic effects. The experimental solubilities in alkaline solution fall within the framework of the above description. In the examples of DER with more than one uptake, the decrease in alkali solubility varies significantly with the percent weight gains. In general, the extent of change in a given property as a result of chemical modification is directly related to the degree of modification, as mentioned previously ${ }^{9}$.

\section{References}

1) H. Shiozaki and Y. Tanaka; Makromol. Chem., 138, 215 (1970).

2) Y. Tanaka and H. Shiozaki; Proc. 5th Inter. Wool Text. Res. Conf., Aachen, 1975, vol. III. p 192.

3) H. Shiozaki and Y. Tanaka; Sen-i Gakkaishi, 28, 174 (1972).

4) C. W. Capp and J. B. Speakman; J. Soc. Dye. $\mathrm{Col}_{0}, 65,402$ (1949).

5) C. Fernley and J. B. Speakman; Nature, 166, 743 (1950).

6) Y. Tanaka and H. Shiozaki; Proc. 6th Inter. Wool Text. Res. Conf., Pretoria, 1980, vol. II, p 369.

7) H. Zahn and H. Wilhelm; Text. Res. J., 23, 604 (1953).

8) J. C. Griffith; Text. Res. J., 35, 1046 (1965).

9) H. Shiozaki and Y. Tanaka; Makromol. Chem., 129, 12 (1969): ibid., 143, 25 (1971): ibid., 152, 217 (1972): J. Polymer Sci., A-1, 8, 2791 (1970): Angew. Makromol. Chem. 64, 1 (1977). 
10) J. B. McKelvey, R. R. Benerito, R. J. Berni, and B. G. Burgis; J. Appl. Polymer Sct., 7, 1371 (1963).

11) Y. Tanaka and T. F. Mika; "Epoxy Resins" (C. A. May and Y. Tanaka, eds), Dekker, New York, 1973, Chapter 3.

12) M. Sakamoto, K. Kajiyama, M. Iwata, and H. Tonami; Proc. Inter. Wool Text. Res. Conf., Aachen, 1975, vol. 111, p 125: M. Sakamoto, K. Kajiyama, Y. Sato, and F. Nakayama; ibid., vol. V, p 339.

13) J. O. Edwards; J. Amer. Chem. Soc., 76, 1540 (1954): ibid., 78, 1819 (1956).

14) H.G.B. de Jong; Kolloidchem. Beih., 48, 33 (1938).

15) E. L. Smith; J. Biol. Chem., 108, 187 (1935).
16) B. D. Davis and E. J. Cohn; J. Amer. Chem. Soc., 61, 470 (1941).

17) H.M. Dawson and W. Lowson; J. Chem. Soc., 135, 1217 (1921).

18) R. E. Parker and N. S. Isaacs; Chem. Rev., 59, 737 (1959).

19) E. J. Cohn and J. T. Edsall; "Proteins, Amino Acids, and Peptides as Ions and Dipolar Ions", Reinhold, New York, 1943, p 84.

20) H. Haurowitz; "Chemistry and Biology of Proteins", Academic, New York, 1950, Chapter 5.

21) J. E. Leffer and E. Grunwald; "Rates and Equilibria of Organic Reactions", Wiley, New York, 1963, p 243.

22) N. H. Koenig; Text. Res. J., 35, 708 (1965).

\section{多官能性エポキシドと羊毛ケラチンとの付加反応}

\section{䋐維高分子材料研究所 神奈川県工業試験所 \\ 由中芳滩 \\ 塩崎英樹}

羊毛よ 2 及び 3 官能性アルキル及びアリールグリシジ ルエーテルとの不均一付加反応を，四塩化炭素やトルエ ンなどの溶媒中， $50 \sim 70^{\circ} \mathrm{C}, \mathrm{NaCl}$ な゙種々の塩水溶液 を含浸触媒として用い調べだ。反応は塩やエポキシド， 溶媒の量や性質及び反応温度に左方された。即ち反应速 度は塩濃度之共に増大するがある震度で最大值を上った。 塩の効果は塩アニオンの塩基性もしくは求核性で説明さ れた。羊毛ケラチンのリジン。ヒスチジン，アルギニン
及びシスチン残基の他に，チロシンとセリン残基へのエ ポキシドの付加加確められた。エポキシドの付加㽬は更 にアスパラギン酸やグルタミン酸残基への付加髭で説明 できるが，蛋白質の架橋反応以外の単な゙るエポキシトの 付加も起っていると推定さ机る。過ギ酸/アンモニア溶 液やアルカリ溶液への好理羊毛の溶解試験では，前者へ の溶解度はいずれあ大きく低下したが，绪者へはレゾル シン系エポキシドを除いて溶解性は增加した。 